\title{
Identification of students' science process skills in Basic Physics Practicum II in using e-module
}

\author{
Artha Lumbantoruan*, Dear Lumbantoruan, Neng Ria Nasih, Sofia Christine Samosir, Utari \\ Prisma Dewi, Dodi Setiawan Putra, Orin Hidayusa Wiza \\ Universitas Jambi, Indonesia \\ Email: artha.lumbantoruan16@gmail.com
}

Didik Irawan, Harina Remalis Siregar

SMAS Yadika Jambi, Indonesia

\begin{abstract}
Good science process skills demonstrated by the attitude of students in conducting experiments in the laboratory. This study aims to determine the mastery of science process skills of students of Physics Education in Universitas Jambi, both students who use the printed Guidebook and students who use the e-module as guide in practicum activities by reviewing eight aspects of integrated science process skills. This study uses a quantitative approach with experimental research methods, namely true experimental. In the study sample used was a student of Physics Education were divided into two groups, 35 students for experiment class and 30 students for control class. Assessment instruments used were observation sheet science process skills with a score of skills used in the form of Likert scale. Based on the analysis score mastery of integrated science process skills of students in the experimental class, operationally defining variables have the highest percentage of $51.4 \%$ to the category of very good, whereas in the control class, analyzing aspects of investigations has the highest percentage of $53.3 \%$ with a good category.
\end{abstract}

Keywords: college, integrated science process skills, practicum, reflection on a flat mirror

\section{Introduction}

Education is a conscious effort and planned to create an atmosphere of learning and the learning process so that learners are actively developing their potentials. Education in Indonesia has integrated well and needs further development. Sustainability education should be closely linked to the curriculum used. The curriculum has two aspects items, namely as a plan that must be used as a guideline for the implementation of the teaching and learning process, and as a tool to achieve educational goals [1]. Frequent alternation of the curriculum in schools due to the curriculum is appropriate or not appropriate when it is applied. The curriculum is currently used is the revised 2013 curriculum, so that students are expected to have a scientific attitude in the learning [2].

The students' positive attitude towards the eyes of Physics Subjects will be integrated with the Social Implications of Physics Subjects, scientific attitudes, learning pleasure in Physics Subjects, interest in increasing time to study Physics Subjects, and interested in a career in Physics Subjects[3]. Scientific attitude helps learners to understand the concepts of science so as to perform science experiments to spark an understanding and insight into understanding the science itself [2]. Science has been introduced from primary education, Science is an ongoing learning process [4]. Beliefs, feelings and actions are the three main components of which are owned scientific attitude can be applied through the use of scientific methods to form an active attitude, independent, critical thinking, logical and structured [5]. The scientific attitude is an attitude that must be Possessed by students in learning science such as honesty, curiosity, responsible, conscientious, discipline, and others [6].

One of the processes of scientific inquiry can be Carried out by practicum activities [7]. Experimental activities aimed to assist students to acquire knowledge independently, such experiments Physics. Physics laws and principles gained through the success of the experiment the scientists. This success is supported by the 
skills of the scientists in the experiment can be summarized in science process skills (SPS). Science process skills is a skill that provides a means of learning science, research, and learning that is active, building a sense of responsibility during the learning and increase knowledge [8].

Science process skills are important for every student in preparation to use scientific methods in developing science and is expected to gain new knowledge or develop the knowledge that has been held [9]. Students who have science process skills can practice understanding the concepts they have acquired in learning activities roommates have two categories, basic science process skills and integration of science process skills [10]. Especially for students aiming Physics Education as a prospective educator. As a candidate for professional educators, students have a duty to guide, train and develop one's knowledge [11]. Science process skills needed by the students as prospective teachers to have pedagogic competence of the which is expected to be a time of skills and expertise directly into the field [12]. Physics education study program has a goal to produce graduates who are skilled in various aspects of competence, especially skill competence [13]. Because science process skills emphasize the learning process, accreditation, creativity, values and Also the attitude of a student who will later be applied in daily life, so science process skills have a relationship with the motivation of a student [14]. To practice science process skills of students, it is necessary to conduct experiments Guidebook is based on aspects of science process skills.

Wizard-based experiments (SPS) help improve scores on several indicators mastery skills base and SPS SPS integrated [15]. Guidebook used by students, especially in experiments on a flat mirror reflection still use printed books. Reflection on a flat mirror is a physics concept that is studied in physics practicum [16]. Therefore, students need to read the Guidebook containing experimental procedure and a clear sequence. However, Guidebook is available in the form of a printed book. This makes it difficult to read the Guidebook students to learn anywhere. It is also described by [17] which says that students Realize that the use of smartphones, as learning media, give a positive impact on students learning. Thus the necessary collaboration between the Guidebook for experimental activities with the progress of science and technology today. The use of e-books is not new today. The use of smartphone applications to support learning media become a necessity for students. Therefore, use-based Guidebook online through the website. The use of web-based learning media shows the advantages of getting online information without having to download applications so that it makes it easy for students to use practicum guidebooks anytime and anywhere [18].

\section{Research Methods}

This study used a quantitative approach with experimental research methods, namely true experimental. True experiments comprise the most rigorous and strong experimental designs because of equating the groups through random assignment[19]. The purpose of this study to identify the science process skills of students using e-module in Practicum Physics II, particularly the experimental reflection on a flat mirror, so this research using the post-test end-experimental control group design.

\section{Experimental Control

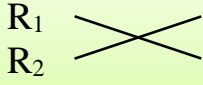 \\ $\mathrm{O}_{1}$ \\ $\mathrm{O}_{2}$}

Figure 1. The post-test end-experimental control group design.

Design of this research, there are two groups of experimental and control groups. The experimental group was given treatment by using e-module on a flat mirror material. The measurement results are given treatment group called $\mathrm{O}_{1}$. While the control group was given no treatment, control group using printed Guidebook which produces measurement called the $\mathrm{O}_{2}$.

Participants in this study were students of the second semester of Physics Education who is contracted courses Basic Physics II, The sample used in this study was conducted by random sampling. In the study sample used was a student of physics education amounted to 65 people, who were divided into two groups at random to obtain grade 35 students to 30 students to experiment and control class.

Assessment instruments used were observation sheet science process skills with a score of skills used in the form of Likert scale. Election four scale is intended to adjust the desired criteria by researchers, namely: 1) Very Bad; 2) Bad; 3) Good; and 4) Very Good. In this study only uses 8 indicators for the assessment of 
student basic science process skills of observing the student basic science process skills of observation, using a relationship, classify, use numbers, measure, communicate, predict and infer.

Data science process skills of students were analyzed using descriptive statistics. Then analyzed using statistical difference test using the t-test for determining student mastery of science process skills that are grouped into four criteria as in Table 1.

Table 1. The interval for each aspect of Science Process Skills

\begin{tabular}{lcccc}
\hline \multicolumn{1}{c}{ Aspect of SPS } & \multicolumn{4}{c}{ Interval } \\
\cline { 2 - 5 } & Very Bad & Bad & Good & Very Good \\
\hline Identifying variables & $3.00-5.25$ & $5.26-7.50$ & $7.51-9.75$ & $9.76-12.00$ \\
\hline Arranging graphs & $2.00-3.50$ & $3.51-5.00$ & $5.01-6.50$ & $6.51-8.00$ \\
\hline Obtaining and processing of data & $2.00-3.50$ & $3.51-5.00$ & $5.01-6.50$ & $6.51-8.00$ \\
\hline Analyzing investigations & $2.00-3.50$ & $3.51-5.00$ & $5.01-6.50$ & $6.51-8.00$ \\
\hline Making a hypothesis & $1.00-1.75$ & $1.76-2.50$ & $2.51-3.25$ & $3.26-4.00$ \\
\hline Defining variables operationally & $4.00-7.00$ & $7.10-10.00$ & $10.10-13.00$ & $1.10-4.00$ \\
\hline Designing investigations & $1.00-1.75$ & $1.76-2.50$ & $2.51-3.25$ & $3.26-4.00$ \\
\hline Experimenting & $14.00-24.50$ & $24.51-35.00$ & $35.01-45.50$ & $45.51-56.00$ \\
\hline
\end{tabular}

\section{Results and Discussion}

Science process skills are all skills needed to acquire, develop, and apply the concepts, principles, laws, and theories of science in the form of mental ability, physics, and social skills [20]. Physics Education Students come from backgrounds in different schools. Therefore, early knowledge of Physics Education student is influenced by physics learning gained in school. The novelty of this study is to define science process skills integrated education students Physics in Universitas Jambi by reviewing eight aspects (identifying variables, arranging graphs, obtaining and processing of data, analyzing investigations, making a hypothesis, defining variables operationally, designing investigation, and experimenting) experimenter material reflection on a flat mirror in the laboratory. Physics investigations by the way that students acquire the experimental data, by observing and decide what tools need to be used, and make hypotheses [21].

In this study, students in doing practicum using modules based on digital or e-module as Guidebook. Emodule made about aspects of science process skills combined with the use of the website as a forum that connects students with practicum module guide. Thus, students are expected to acquire media that can train their SPS, anytime and anywhere.

Table 2.T-test Result

\begin{tabular}{|c|c|c|c|c|c|}
\hline & & \multicolumn{2}{|c|}{$\begin{array}{c}\text { Levene's Test for } \\
\text { Equality of } \\
\text { Variances } \\
\end{array}$} & \multicolumn{2}{|c|}{$\begin{array}{c}\text { t-test for Equality of } \\
\text { Means }\end{array}$} \\
\hline & & $\mathbf{F}$ & Sig. & $\begin{array}{l}\text { Sig. (2- } \\
\text { tailed) }\end{array}$ & $\begin{array}{c}\text { Mean } \\
\text { Difference }\end{array}$ \\
\hline \multirow[t]{2}{*}{$\begin{array}{l}\text { INTEGRATED } \\
\text { SPS }\end{array}$} & $\begin{array}{l}\text { Equal } \\
\text { variances } \\
\text { assumed }\end{array}$ & .531 & .469 & .022 & 6.65238 \\
\hline & $\begin{array}{l}\text { Equal } \\
\text { variance not } \\
\text { assumed }\end{array}$ & & & .023 & 6.65238 \\
\hline
\end{tabular}

Based on the results of the t-test in Table 2, the Sig. Levene's Test for Equality of Variances is 0.469> 0.05 , so the data variance between the experimental class and the control class is homogeneous. Therefore, the right information that can guide us from Table 2 is the value contained in the Equal variances assumed. Based on the t-test, it can be seen that Sig. (2-tailed) $<0.05$. This shows that there is a significant difference in the integrated SPS mastery score between the experimental class and the control class. The results of the analysis 
of the science process skills of students based on the observation of the experimental class and control class can be seen in Table 3 .

Table 3. Analysis of integrated science process skills mastery of students of Physics Education in Universitas Jambi

\begin{tabular}{llcccc}
\hline \multirow{2}{*}{ Class } & \multicolumn{1}{c}{ Aspect of SPS } & Min & Max & mean & $\begin{array}{c}\text { Std. } \\
\text { deviation }\end{array}$ \\
\hline \multirow{5}{*}{ Experimental } & Identifying variables & 7.00 & 11.00 & 9.49 & 1.01087 \\
\cline { 2 - 6 } & Arranging graphs & 4.00 & 8.00 & 6.54 & 1.29121 \\
\cline { 2 - 6 } & Obtaining and processing of data & 2.00 & 8.00 & 6.11 & 1.56753 \\
\cline { 2 - 6 } & Analyzing investigations & 4.00 & 8.00 & 6.31 & 1.27813 \\
\cline { 2 - 6 } & Making a hypothesis & 2.00 & 4.00 & 3.37 & 0.64561 \\
\cline { 2 - 6 } & Defining variables operationally & 8.00 & 16.00 & 13.03 & 1.94763 \\
\cline { 2 - 6 } & Designing investigations & 2.00 & 4.00 & 3.37 & 0.68966 \\
\cline { 2 - 6 } & Experimenting & 35.00 & 53.00 & 45.11 & 1.13241 \\
\hline \multirow{4}{*}{ Control } & Identifying variables & 5.00 & 12.00 & 8.33 & 2.05667 \\
\cline { 2 - 6 } & Arranging graphs & 4.00 & 8.00 & 5.63 & 1.21721 \\
\cline { 2 - 6 } & Obtaining and processing of data & 8.00 & 6.13 & 1.16658 \\
\cline { 2 - 6 } & Analyzing investigations & 2.00 & 8.00 & 6.43 & 1.10433 \\
\cline { 2 - 6 } & Making a hypothesis & 4.00 & 3.00 & 0.87099 \\
\cline { 2 - 6 } & Defining variables operationally & 2.00 & 16.00 & 12.03 & 2.04237 \\
\cline { 2 - 6 } & Designing investigations & 4.00 & 2.97 & 0.71840 \\
\cline { 2 - 6 } & Experimenting & 51.00 & 36.7 & 9.99707 \\
\hline
\end{tabular}

From Table 3, it can be seen that the students in the experimental class (using the e-module) has good science process skills than students in the control class (do not use e-module). This is shown clearly that in each indicator, integrated science process skills have the highest maximum in the experimental class. Also, the average score on each indicator of science process skills in the experimental class showed higher scores than the control class. Scores mastery of integrated science process skills of students in more detail described in Table 4.

Table 4. Scores mastery of integrated science process skills Physics Education student in Universitas Jambi

\begin{tabular}{|c|c|c|c|c|c|}
\hline \multirow[t]{2}{*}{ Class } & \multirow[t]{2}{*}{ Aspect of SPS } & \multicolumn{4}{|c|}{ Category } \\
\hline & & $\begin{array}{c}\text { Very } \\
\text { Good } \\
(\%)\end{array}$ & $\begin{array}{c}\text { Good } \\
(\%)\end{array}$ & $\begin{array}{l}\text { Bad } \\
(\%)\end{array}$ & $\begin{array}{l}\text { Very } \\
\text { Bad } \\
(\%)\end{array}$ \\
\hline \multirow[t]{8}{*}{ Experimental } & Identifying variables & 42.9 & 54.3 & 2.8 & 0 \\
\hline & Arranging graphs & 48.6 & 37.1 & 14.3 & 0 \\
\hline & Obtaining and processing of data & 48.6 & 28.6 & 17.1 & 5.7 \\
\hline & Analyzing investigations & 45.7 & 34.3 & 20.0 & 0 \\
\hline & Making a hypothesis & 45.7 & 45.7 & 8.6 & 0 \\
\hline & Defining variables operationally & 51.4 & 37.1 & 11.4 & 0 \\
\hline & Designing investigations & 48.6 & 40.0 & 11.4 & 0 \\
\hline & Experimenting & 45.7 & 48.6 & 5.7 & 0 \\
\hline \multirow[t]{8}{*}{ Control } & Identifying variables & 30.0 & 36.7 & 16.7 & 16.7 \\
\hline & Arranging graphs & 16.7 & 43.3 & 40.0 & 0 \\
\hline & Obtaining and processing of data & 26.7 & 46.7 & 26.7 & 0 \\
\hline & Analyzing investigations & 36.7 & 53.3 & 36.7 & 0 \\
\hline & Making a hypothesis & 36.7 & 26.7 & 36.7 & 0 \\
\hline & Defining variables operationally & 26.7 & 43.3 & 30.0 & 0 \\
\hline & Designing investigations & 23.3 & 50.0 & 26.7 & 0 \\
\hline & Experimenting & 20.0 & 43.3 & 20.0 & 16.7 \\
\hline
\end{tabular}

Based on the information in Table 4, it can be concluded that students of Physics Education in Universitas Jambi have a mastery science process skills in good category. This is indicated by the percentage of each 
indicator are in either category. However, students in the experimental class have a higher percentage than students in the control class.

Science process skills are the skills needed to support the activities of practicum students are doing in the lab. This capability consists of two types of science process skills, ie basic science process skills and integrated science process skills. Basic science process skills including observation, classification, communication, measuring, make inferences, predictions, identifying variables, and create a data table. In essence, the basic science process skills students should master before the integrated science process skills. In this research is reviewed 8 indicators integrated science process skills that include identifying variables, arranging graphs, Obtaining and processing of data, analyzing investigations, making a hypothesis, operationally defining variables, designing investigation,

As one of the integrated science process skills, identifying variables requires more advanced basic knowledge [22]. In the aspect of identifying variables skills, three things need to be observed that the ability of students to express an independent variable, the dependent variable, and constant variables appropriately. In this aspect, $16.7 \%$ of the students in the experimental class free to determine the control variables. Meanwhile, students in the class in part control, free to express the variables that exist in experimental activities. Students more trusting his argument than his own.

A further aspect is arranging the graphs. These skills are closely related to the data table making skills, the better the skills of making the data table the better the graphs arranging skills. Students in the class experiment are in the very good category, while students in the control class that are in the good category. Students in the experimental class that can identify the variables in the experiment, keen to make some graphs relating to the variable that is identified. While students in the control class, simply create a graph of an example in which the module is printed. Most students are less interested in communicating the results of its findings through graphs. This indicates that the student has not had a good attitude [23]. Also, the limitations of the findings are presented through a table of data is one factor that makes students lazy to communicate its findings through data tables. Therefore, graphs arranging skills can affect other skills such as Obtaining and processing data.

In indicator Obtaining and processing of data, in terms of students' ability to display data in tabular form the results of experimental data and graphs. But the control students in the class students should have previous experience observing, classifying, and measuring before interpreting the data [22]. Students' ability to demonstrate findings are closely related to basic science process skills possessed by students. While analyzing indicators investigations, reviewing the student's ability to adjust and decide that experiments are done by the hypothesis. In this case, the student should have confidence in the idea to design and plan the experiments have been thinking. Therefore, the ability to analyze investigations are closely related to aspects of making hypothesis. The hypothesis is a statement based on Assumptions and has not been proven [15], Aspects of making hypothesis is measured by reviewing a student's ability to hypothesize based on objective and analytical tools and practicum materials to be used in experiments. Usually, the hypotheses are used in Determining theory and law [15].

Aspects operationally defining variables are reviewed through the students' ability to recognize the variables and provide treatment according to the variables. The operational definition tells what to do and what is observed [24], For example, in experiments on a flat mirror reflection, students should be able to understand the relationship of independent variables (the object distance) and dependent variable (the distance the shadow). Thus, students tend to perform measurements of the distance of objects in front of the mirror and then measuring the distance shadows against a mirror. A good student in the experimental class and control class has the skill with a good category. Furthermore, the investigation designing aspects which include the ability of students to determine which tools and materials, as well as the experimental procedure. Aspects of designing skills of the investigation consisted of designing skills of investigation/research, skills of conducting investigations/research, and skills of reporting the results of the investigation [25].

The last aspect which is seen from this study are experimenting that looked at the ability of students inappropriate equipment and materials practicum objectives, and conduct experiments by the experimental measures presented by e-module. The experiment includes using the materials needed to create a mechanism that suits the purpose of practice, change and control variables to reach the data, records and Evaluate the data to analyze it, draw Conclusions and provide reports about the experiments conducted [26]. Students in the experimental class can conduct experiments well as the experimental procedure described in the e-module coherently. While students in the control classes tend to require an action demonstration lab assistant to help 
him understand the experimental procedure. Therefore, about $20 \%$ of the students in the control class in the category Bad.

Some indicators of interest in the observations made, it can be concluded that the students of Physics Education in Universitas Jambi have mastery of science process skills are classified in the category of good. However, each class has the aspect of a dominant science process skills that operationally defining variables for class experiments, and analyzing aspects of investigations for the control class. Each class has its way (posture) to do the practicum. Attitude to learning is important, so even with the existing attitude to learning about college courses [27]. Students in the experimental class are also capable of using direct e-module in the laboratory without demonstrated. This shows that the students are familiar with the e-module.

The mastery of integrated science process skills in students which is classified as good shows that Physics Education students have good competence as prospective educators, especially in the field of Physics. This also indicates that the use of e-modules in practical work is effective to support student skills in science processing. This is consistent with the results of research Ref [28] which states that the use of e-modules can improve the science process skills of students in higher education. But, in research of Ref [28] reviewed the basic science process skills in the Reflecting Practices in Flat Mirror. However, not only basic skills but also integrated science process skills also showed improvement.

\section{Conclusion}

Based on the analysis score mastery of integrated science process skills of students, it can be concluded that the students of Physics Education in Universitas Jambi classified in the category of good. However, the experimental class and the control class has a dominant aspect of each. In the experimental class, operationally defining variables have the highest percentage of $51.4 \%$ to the category of very good, whereas in the control class, analyzing aspects of investigations has the highest percentage of $53.3 \%$ with the good category.

\section{Acknowledgement}

We would thank the chairman of the physics education which has allowed us to work together. Also, we want to thank the chairman of the physics education laboratory in Universitas Jambi, who has Provided the opportunity to be able to research the physics laboratory education in Universitas Jambi. Besides that, thank you to all of the Physics Education students who have participated in this research.

\section{References}

[1] S. Syahrial, A. Asrial, D. A. Kurniawan, F. Chan, A. Hariandi, R. A. Pratama, P. Nugrogo, and R. Septiasari, "The impact of etnocontructivism in social affairs on pedagogic competencies." International Journal of Evaluation and Research in Education (IJERE), vol. 8 no. 3, pp. 409-416, 2019.

[2] J. Jufrida, W. Kurniawan, A. Astalini, D. Darmaji, D. A. Kurniawan, and W. A. Maya. "Students' Attitude and Motivation In Mathematical Physics," International Journal of Evaluation and Research in Education (IJERE), vol. 8 no. 3, pp. 401-408, 2019.

[3] R. Perdana, C. Subiyantoro, and L. Anggraini. "Sikap dan Motivasi pada Mata Pelajaran Fisika," SPEKTRA, vol. 5, no. 2, pp. 178-187, 2019.

[4] D. A. Kurniawan, Astalini, and L. Anggraini, "Evaluasi Sikap Siswa Smp Terhadap IPA Di Kabupaten Muaro Jambi," J. Ilm. Didakt. VOL., vol. 19, no. 1, pp. 124-139, 2018.

[5] Astalini, K. Dwi Agus, and Sumaryanti, "Sikap Siswa Terhadap Pelajaran Fisika di Sman Kabupaten Batanghari," J. Ilmu Pendidik. Fis., vol. 3, no. 2, pp. 59-64, 2018.

[6] D. A. Kurniawan, Astalini, A. Susanti, and Maison, "Attitudes of College Students on the Subject of Mathematical Physics III in Physics Education Program of Jambi University," Educ. Rev. USA, vol. 2, no. 11, pp. 505-513, 2018.

[7] Darmaji, D. A. Kurniawan, and Irdianti, "Physics education students' science process skills," Int. J. Eval. Res. Educ., vol. 8, no. 2, pp. 293-298, 2019.

[8] Darmaji, D. A. Kurniawan, and A. Lestari, "Deskripsi keterampilan proses sains mahasiswa pendidikan fisika pada praktikum suhu dan kalor," J. Ris. dan Kaji. Pendidik. Fis., vol. 5, no. 2, pp. 68-72, 2018.

[9] Darmaji, Astalini, A. Rahayu, and Maison, "Pengembangan Penuntun Praktikum Fisika Berbasis Keterampilan Proses Sains Menggunakan Model Problem Solving,” EDUSAINS, vol. 10, no. 1, pp. 83-96, 2018. 
[10] S. S. Liew, H. L. Lim, S. Saleh, and S. L. Ong. "Development of Scoring Rubrics to Assess Physics Practical Skills," EURASIA Journal of Mathematics, Science and Technology Education, ISSN: 1305-8223, vol. 15 no. 4 , em 1691, 2018.

[11] R. O. Ongowo, and F. C. Indoshi. "Science Process Skills in the Kenya Certificate of Secondary Education Biology Practical Examinations," Creative Education, vol. 4 no. 11, pp. 713-717, 2013.

[12] M. Karadan, and D. A. Hameed. "Curricular Representation of Science Process Skills in Chemistry," IOSR Journal of Humanities and Social Science, vol. 21 no. 8, pp. 1-5, 2016.

[13] G. K. Yumusak. "Science Process Skills in Science Curricula Applied in Turkey," Journal of Education and Practice, vol. 7, no. 20, pp. 94-98, 2016.

[14] Maison, Darmaji, Astalini, D. A. Kurniawan, and P. S. Indrawati, "Science process skills and motivation," Humanit. Soc. Sci. Rev., vol. 7, no. 5, pp. 48-56, 2019.

[15] Darmaji, D. A. Kurniawan, A. Suryani, and A. Lestari, “An Identification Of Physics Pre-Service Teachers ' Science Process Skills Through Science Process Skills -Based Practicum Guidebook,” J. Ilm. Pendidik. Fis. AlBiRuNi, vol. 07, no. October, pp. 239-245, 2018.

[16] Myers, R. L. "The Basics of Physics," London: Greenwood Press, 2013.

[17] Vyas, N., \& Nirban, V. (2014). Students' Perception on the Effectiveness of Mobile Learning in an Institutional Context. ELT Research Journal, 3(1), 26-36. Retrieved from http://dergipark.gov.tr/eltrj/issue/5481/74444.

[18] Papadakis, S., Kalogiannakis, M., Sifaki, E., \& Vidakis, N. (2018). Evaluating Moodle use via Smart Mobile Phones. A case study in a Greek University. EAI Endorsed Transactions on Creative Technologies,5(16),doi: 10.4108/eai.10-4-2018.156382.

[19] J. W. Creswell, "Educational Research: Planning, Conducting and Evaluating Quantitativ and Qualitativ Research," Lincoln: University of Nebraska, 2012.

[20] Y. Yuliati, "Peningkatan Keterampilan Proses Sains Siswa Sekolah Dasar Melalui Model Pembelajaran Berbasis Masalah," Jurnal Cakrawala Pendas, vol. 2 no. 2, pp. 71-83, 2016.

[21] E. Ediansyah, D. A. Kurniawan, R. Perdana, and S. Salamah. "Using Problem-Based Learning in College: Mastery Concepts Subject Statistical Research and Motivation," International Journal of Evaluation and Research in Education (IJERE), vol. 8 no. 3, pp. 446-454, 2019.

[22] S. Ozgelen, "Students' Science Process Skills within a Cognitive Domain Framework," Eurasia Journal of Mathematics, Science \& Technology Education,” vol. 8 no. 4, pp. 283-292, 2012.

[23] L. Anggraini, and R. Perdana. "Hubungan Sikap dan Percaya Diri Siswa Pada Mata Pelajaran IPA di Sekolah Menengah Pertama," SPEKTRA, vol. 5 no. 2, pp. 188-199, 2019.

[24] N. Hidayah, M. Arifuddin, and A. I. Mahardika, "Meningkatkan Keterampilan Proses Sains Pada Pembelajaran Fisika Menggunakan Metode Percobaan,” Berkala Ilmiah Pendidikan Fisika, vol. 5 no. 2, pp. 198-212, 2017.

[25] B. Subali, "Pengukuran Kreativitas Keterampilan Proses Sains Dalam Konteks Assessment For Learning," Jurnal Cakrawala Pendidikan, vol. 1 no. 1. pp. 130-144, 2011.

[26] Rezba, R. J., Sprangue, C., McDonnough, J. T., \& Matkins, J. J. Learning and Assessing: Science Process Skills $5^{\text {th }}$ Edition. USA: Kendall/Hunt Publishing Company, 2007.

[27] S. Susbiyanto, D. A. Kurniawan, R. Perdana, and C. Riantoni. "Identifying the Mastery of Research Statistical Concept by Using Problem-Based Learning," International Journal of Evaluation and Research in Education (IJERE), vol. 8 no. 3, pp. 461-469, 2019.

[28] Astalini, Darmaji, W. Kurniawan, K. Anwar, and D. A. Kurniawan, "Effectiveness of Using E-Module and EAssessment,” Int. J. Interact. Mob. Technol., vol. 13, no. 9, pp. 21-39, 2019. 